\title{
PEMANTAUAN PERKEMBANGAN ANAK DENGAN DDST II PGTK PAUD PELITA HATI RANCABANGO GARUT
}

\author{
Sri Yekti Widadi ${ }^{1}$, Iin Patimah ${ }^{2}$, Zesi Nurani ${ }^{3}$, Riswan Safaat ${ }^{4}$, Endah Nur Tri ${ }^{5}$,Aa \\ Sofyan ${ }^{6}$, Hesti Suci $^{7}$, Yudi Suwandi ${ }^{8}$ \\ ${ }^{1-8}$ Program Studi Profesi Ners STIKes Karsa Husada Garut \\ Jln. Nusa Indah no. 24 Garut Jawa Barat \\ SriYYekti_s@yahoo.com
}

\begin{abstract}
ABSTRAK
Latar Belakang : Proses perkembangan pada anak-anak didasari pada aspek perkembangan fisik yang meliputi motorik halus dan motorik kasar, serta perkembangan sosio emosional, bahasa, dan perkembangan kognitif. Metode yang digunakan untuk menilai perkembangan anak salah satunya menggunakan instrumen Denver Development Screening Test II (DDST II). PGTK Paud Pelita Hati merupakan play group dan taman kanak-kanak yang berada di kota Garut. Belum dilakukannya pemeriksaan perkembangan pada anak PGTK Pelita Hati dikarenakan sebagian besar dari guru belum memiliki keterampilan dalam melakukan pemeriksaan perkembangan. Tujuan : Mengetahui gambaran bagaimana perkembangan anak di PGTK Pelita Hati melalui instrumen screening DDST II. Penyelesaian dengan dilakukan dengan melakukan screening perkembangan anak dan melakukan DDST pada anak PGTK Pelita Hati. Hasil : Setelah dilakukan kegiatan pengabdian masyarakat ini diperoleh hasil pemeriksaan perkembangan di PGTK Pelita Hati dapat disimpulkan hampir seluruh anak berada pada kategori normal (87.8\%) dalam penilaian ke empat aspek yang di ujian meliputi personal social, fine motor-adaptive, languange dan gross motor.
\end{abstract}

\section{Kata Kunci : Pengabdian Masyarat, DDST}

\section{ABSTRACT}

Background: The development process in children is based on aspects of physical development which include fine motor and gross motor skills, as well as socio emotional development, language, and cognitive development. One of the methods used to assess child development is using the Denver Development Screening Test II (DDST II) instrument. PGTK Paud Pelita Hati is a play group and kindergarten in the city of Garut. There have not yet been developmental checks on a number of children because most of the teachers do not yet have the skills in conducting development checks. Objective: To find a picture of how the child's development in PGTK Pelita Hati through the DDST II screening instrument. The settlement is carried out by screening the child's development and conducting DDST on the Pelita Hati PGTK child.Results: After this community service activity was obtained the results of development checks at the Pelita Hati PGTK can be concluded that almost all children are in the normal category (87.8\%) in the assessment of the four aspects tested including personal social, fine motoradaptive, languange and gross motor .

\section{Keywords: Community Service, DDST}




\section{PENDAHULUAN}

Anak merupakan individu yang unik dalam kehidupannya, dapat mengalami masa pertumbuhan serta perkembangan. Dimana pertumbuhan dan perkembangan merupakan aspek yang paling penting dalam kehidupan seseorang untuk menentukan dasar kehidupan selanjutnya. Masa depan suatu bangsa dapat tergantung pada pencapaian tahapan pertumbuhan dan perkembangan optimal pada anak. Periode 1000 hari kehidupan merupakan golden period bagi anak sekaligus masa rentan terhadap pengaruh-pengaruh negatif dalam pertumbuhan dan perkembangannya. Stimulasi yang tepat pada usia golden period akan merangsang untuk untuk mencapai tingkat perkembangan terkait kemampuan gerak,bicara, bahasa dan sosialisasi yang optimal sesuai usia anak.

Perkembangan merupakan bertambah sempurnanya fungsi-fungsi alat tubuh yang dapat dicapai melalui belajar dan bertumbuhnya kematangan (Wong, 2009.) Perkembangan anak meliputi perkembangan fisik, kognitif, emosi, bahasa, motorik (kasar dan halus), personal sosial dan adaptif (Soetjiningsih, 2014). Perkembangan juga menjelaskan keadaan anak baik fisik maupun psikososialnya (Susilaningrum, et al. 2013).

Aspek kognitif, fisik, motorik danpsikososial seorang anak berkembang secara pesat dari $50 \%$ menjadi $80 \%$ pada saat usia prasekolah (Kemendiknas 2010). Anak mengalami tumbuh kembang yang luar biasa, baik dari segi fisik, motorik, emosi kognitif maupun psikososial pada masa itu. Salah satu aspek penting pada proses perkembangan anak pada usia prasekolah adalah perkembangan motorik karena merupakan kecerdasan dan emosi sosial (Hurlock dalam Santrock, 2010). Pada dasarnya perkembangan keterampilan motorik berkembang sejalan dengan kematangan syaraf dan otot anak. Setiap gerakan sesederhana apapun merupakan hasil pola interaksi yang kompleks dari berbagai bagian dan sistem dalam tubuh yang dikontrol otak (Revina, 2010).

Berkaitan dengan hal tersebut terdapat sebuah instrumen deteksi kelainan tumbuh kembang anak yang telah terstandar dengan nama DDST. Penggunaan DDST II merupakan pengembangan yang dimulai sejak tahun 1967 yang dikenal dengan Denver Development Materials atau "Denver Scale" yang dibuat di University of Colorado Medical Center di Denver Developmental Screening Test (DDST). (Santoso, 2013). DDST Merupakan metode deteksi yang digunakan secara global menilai kemajuan perkembangan anak sesuai usia. Keterlambatan perkembangan global pada pasien dengan kelainan fisik nyata atau riwayat penyakit berat dapat dianalisisatau dinilai lebih dini, namun hal ini lebih sulit pada pasien dengan fisik normal dan tidak ada riwayat penyakit berat atau penyakit penyerta lainnya (Tjandrajani dkk., 2012.)

Keterlambatan perkembangan dari sektor motorik kasar dan motorik halus apabila ditemukan pada anak maka dicurigai adanya gangguan pada saraf otot serta gangguan susunan saraf pusat pada saraf motorik anak yang dapat mempengaruhi kemampuan anak untuk memahami atau bereksplorasi dengan lingkungan sekitarnya, hal ini berpengaruh pada kemampuan anak dalam memecahkan suatu masalah yang berhubungan dengan berbagai tingkat kreatifitas anak pada tahapan anak periode perkembangan selanjutnya. (Pusponegoro, 2006).

Deteksi dini masalah perkembangan dan perilaku pada anak merupakan suatu hal penting agar dapat memberikan intervensi dini terkait adanya masalah perkembangan yang 
diperoleh dari hasil pengukuran. (Theeranate K, 2005). Sehingga dapat diintervensi dini untuk mengatasi keterlambatan perkembangan dan diupayakan perkembangan anak dapat berjalan optimal sesuai usia.

\section{Screerining DDST II dapat} memberikan manfaat dalam mengidentifikasi masalah dini terutama tumbuh kembang anak. Tes ini merupakan salah satu dari metode screening (deteksi) terhadap kelainan perkembangan anak. Dalam pengabdian masyarakat ini terdapat 4 sektor perkembangan yang menjadi aspek penilaian pada anak yaitu Adaptasi sosial, motorik halus, bahasa dan motorik kasar. Sektor personal sosial berkaitan dengan kemampuan mandiri, sosialisasi dan interaksi dengan lingkungan, sektor motorik halus berkaitan dengan adanya koordinasi antara mata dan tangan, kemampuan memainkan dan dapat menggunakan benda serta pemecahan masalah. Pada sektor bahasa berkaitan dengan kemampuan mendengar, mengerti dan menggunakan bahasa dengan tepat sesuai usia. Kemampuan pada sektor motorik kasar meliputi kemampuan untuk duduk, berjalan, dan melakukan gerakan umum lainnya yang melibatkan pergerakan tubuh (Celikkiran, S, 2015).

Dari hasil studi pendahuluan yang dilakukan khususnya PGTK Paud Pelita Hati Rancabango Garut belum pernah dilakukan pemeriksaan perkembangan pada anak.

$$
\text { Berdasarkan latar belakang }
$$

Tersebut di atas, pentingnya dilakukan screening perkembangan anak dengan menggunakan metode Denver Development Screening Test II. Dengan skrining ini diharapkan dapat mengetahui perkembangan anak sesuai dengan tahapan usia .

\section{METODE}

Kegiatan ini dilakukan di aula rapat PGTK Pelita Hati Rancabango Garut Kota. Kegiatan pemeriksaan menggunakan DDST II. Jumlah anak yang diperiksa adalah 33 anak PGTK dari usia 4-6 tahun. Alat yang dipersiapkan menggunakan DDST kit yang terdiri dari : (Gulungan benang wool berwarna merah (dengan diameter $10 \mathrm{~cm}$ ), Kismis, Kerincingan dengan gagang yang kecil, 10 bh kubus berwarna dg ukrn 2,5 cm x 2,5 cm, Botol kaca kecil dengan diamater lubang 1,5 cm, Bel kecil , Bola tenis, Pinsil merah, Boneka kecil dengan botol susu, Cangkir plastik dengan gagang/ pegangan, Kertas kosong) serta formulir denver.

\section{HASIL DAN PEMBAHASAN}

Kegiatan pengabdian masyarakat telah diselenggarakan pada tanggal 28 November 2019, bertempat di Aula rapat PGTK Pelita Hati, yang diikuti sebanyak 33 anak PGTK. Kegiatan pengabdian masyarakat yang telah dilakukan, terdiri dari beberapa rangkaian kegiatan, dimulai dari persiapan kegiatan, pelaksanaan kegiatan, evaluasi kegiatan serta dokumentasi.

Pelaksanaan pengabdian masyarakat diawali dengan tahapan persiapan, pada tahapan ini tim pengabdian masyarakat yang terdiri dari dosen STIKes karsa Husada Garut beserta mahasiswa menyiapkan beberapa peralatan dan instrument yang diperlukan dalam kegiatan ini yaitu diantaranya: mempersiapkan DDST Kit dan formulir DDST II. izin kegiatan pengabdian masyarakat melalui kesatuan bangsa dan politik (Kesbangpol) Kabupaten Garut serta perizinan Kepala sekolah PGTK Pelita Hati Rancabango Garut Kota. PGTK Pelita Hati sebagai tempat kegiatan 
yang akan dilakukan pemeriksaan perkembangan anak. Tahapan persiapan telah direncanakan dan difasilitasi dengan baik; DDST kit telah disediakan sebanyak 33 anak PGTK dan Formulir juga sudah tersedia, serta aula yang mendukung untuk tempat dilakukannya perkembangan.

pemeriksaan

Tahapan selanjutnya yang dilakukan dalam kegiatan ini adalah tahap pelaksanaan, pelaksanaan dilakukan dengan pemeriksaan pada masing masing anak yang didampingi oleh satu atau orang tua wali. Data dikumpulkan dengan lembar penilaian Denver Development Screening Test (DDST) II, dan simulasi sesuai dengan petunjuk dalam lembaran DDST II. Penilaian dilakukan melalui beberapa langkah. Pertama, menilai usia anak saat pemeriksaan. Kedua, membuat garis pada lembar DDST II sesuai usia yang telah ditentukan. Ketiga, melakukan pengukuran pada tiap komponen dimulai dari tiga item di sebelah kiri garis usia. Pengukuran dilakukan pada 4 aspek yakni personal sosial, motorik halus, bahasa dan motorik kasar. Keempat, melakukan interpretasi hasil pengukuran untuk mengetahui tingkat perkembangan anak. Adapun skor yang diberikan oleh pemeriksa antara lain "P" untuk Pass / Lulus, "F" untuk Fail / Gagal, "NO" untuk No opportunity / Tidak ada kesempatan melakukan tugas dan "R" untuk Refusal.

\section{Tabel 1.1 Distribusi Responden}

\section{Berdasarkan Usia}

\begin{tabular}{|c|c|c|c|}
\hline No & Usia & $\mathbf{N}$ & $\mathbf{\%}$ \\
\hline 1. & 4 Tahun & 8 & 24.2 \\
\hline 2. & 5 Tahun & 20 & 60.5 \\
\hline 3. & 6 Tahun & 5 & 15 \\
\hline & Jumlah & $\mathbf{3 3}$ & $\mathbf{1 0 0}$ \\
\hline
\end{tabular}

Sumber Data Primer, 2019
Tabel diatas menunjukkan bahwa persentase terbesar adalah anak usia 5 tahun $(60,6) \%$ dan presentasi terkecil anak berusia 6 Tahun (15\%)

\section{Tabel 1.2. Distribusi Responden Berdasarkan Jenis Kelamin}

\begin{tabular}{|c|l|c|c|}
\hline No & Jenis Kelamin & $\mathbf{N}$ & $\mathbf{\%}$ \\
\hline 1. & Laki-laki & 15 & 45.5 \\
\hline 2. & Perempuan & 18 & 54.5 \\
\hline & Jumlah & 33 & 100 \\
\hline
\end{tabular}

Sumber : Data Primer, 2019

Tabel di atas menunjukkan bahwa persentase terbesar anak berjenis kelamin perempuan $(54.5 \%)$ dan persentase terkecil anak berjenis lakilaki (45.5\%).

Tabel 1.3 Hasil Penilaian Denver Development Screening Test

\begin{tabular}{|c|l|c|c|}
\hline No & Hasil Tes & $\mathbf{N}$ & $\mathbf{\%}$ \\
\hline 1. & Normal & 29 & 87.8 \\
\hline 2. & Suspect & 2 & 6.06 \\
\hline 3. & Unstestable & $\mathbf{2}$ & 6.06 \\
\hline & Jumlah & $\mathbf{3 3}$ & $\mathbf{1 0 0}$ \\
\hline
\end{tabular}

Sumber : Data Primer 2019

Tabel di atas menunjukkan bahwa persentase terbesar anak berada pada kategori normal (87.8\%) dan persentase terkecil anak berada pada kategori untestable $(6.06 \%)$.

\section{PEMBAHASAN}

Perkembangan pada anak dapat terjadi perubahan bentuk dan fungsi pematangan organ, dalam hal ini menyangkut perkembangan motorik halus, kasar, bahasa dan psikososial, sekitar 16\% dari anak usia dibawah lima tahun (balita) di Indonesia mengalami gangguan perkembangan saraf dan otak 
mulai ringan sampai berat (Depkes, 2008) .

\section{Denver Developmental}

screening test Denver II adalah alat bantu untuk menilai tingkat perkembangan anak usia sesuai dengan tugas untuk kelompok umurnya pada saat melakukan tes. Denver II dapat digunakan untuk memonitor dan memantau perkembangan bayi atau anak dengan resiko tinggi terjadinya penyimpangan atau kelainan perkembangan secara berkala.

Terdapat 125 total item yang dinilai pada lembar observasi DDST II . Fokus penilaian DDST II meliputi Personal sosial, Motorik halus, Bahasa, Motorik kasar. Skoring DDST II meliputi 4 aspek. Advanced; berarti anak mampu melakukan item di sebelah kanan garis usia. OK; berarti anak agal atau menolak melakukan item yang dilalui garis pada persentil 25-75. Caution; berarti anak gagal atau menolak melakukan item yang dilalui oleh garis pada persentil 75-90. Delay; berarti anak gagal melakukan item pada area sebelah kiri garis usia. DDST II bukan suatu tes untuk menilai tingkat kecerdasan anak tetapi suatu metode ini juga tidak untuk mendiagnosa ketidakmampuan dan kesukaran belajar, gangguan bahasa atau gangguan emosional, subtitusi evaluasi diagnostik atau pemeriksaan fisik anak. Tes ini lebih mengarah pada perbandingan kemampuan atau perkembangan anak dengan kemampuan anak lain yang seumurnya.

Hasil pengabdian masyarakat menunjukkan bahwa hampir seluruh anak berada pada kategori normal $(87.8 \%)$. Merujuk pada format penilaian Denver Development Screening test (DDST) II, Bila tidak ada keterlambatan dan atau paling banyak satu caution pada garis kiri usia. Pada kegiatan pengabdian masyarakat ini ditemukan pada anak dengan suspect yaitu sebagian kecil (6,06 \%) Suspect juga menunjukkan bahwa anak gagal melakukan satu atau dua item pada persentil 75-95\%, dimana sebesar 75\%95\% anak pada usia tersebut seharusnya sudah mampu melakukan.

Gangguan perkembangan bisa disebabkan oleh beberapa hal diantaranya hasil penelitian Triastutik, 2018, ada hubungan bermain gadget dengan tingkat perkembangan anak usia 4 -6 Tahun. Dengan gadget anak Diharapkan orang tua dapat membatasi anak dalam durasi bermain gadget dan mengawasi kegiatan yang dilakukan pada anak saat bermain gadget.

Perkembangan balita harus diperhatikan, Hartanto, Selina, \& Fitra (2011) menyatakan terdapat pengaruh antara perkembangan bahasa terhadap perkembangan kognitif pada anak usia 1-3 tahun. Bayi yang mengalami keterlambatan Bahasa awal dapat dinyatakan bahwa ditemukan masalah neurodevelopmental. Keterlambatan bahasa ekspresi dan reseptif oleh para ahli sering dikaitkan dengan kelemahan aspek kognitif secara umum. Keterlambatan terjadi dapat dikarenakan kurangnya stimulasi bahasa dari orang tua ataupendamping balita.

Salah satu aspek penting pada proses perkembangan anak prasekolah adalah perkembangan motorik karena merupakan kecerdasan dan emosi sosial. Terdapat faktor yang memengaruhi perkembangan motorik halus antara lain status gizi, riwayat kelahiran, pola asuh, stimulasi dan kesehatan.

Gizi berperan penting dalam pertumbuhan dan perkembangan anak. Di Indonesia, spektrum malnutrisi sangat luas dan terjadi di seluruh tahap kehidupan antara lain dalam bentuk Kurang Energi Protein (KEP), kekurangan zat gizi mikro, bera $t$ bayi lahir rendah, dan gangguan pertumbuhan yang dilihat dari indikator tinggi badan menurut umur. Selaras 
dengan penelitian Solihin , 2013 bahwa Tingkat kecukupan gizi balita, terutama energi dan protein, berhubungan dengan status gizi dan perkembangan .

Pola asuh orang tua merupakan interaksi antara orang tua dan anak dalam berkomunikasi, mendidik, mengasuh, dan terus berkelanjutan dari waktu kewaktu. Dengan pola asuh yang diterapkan orang tua anak dapat berinteraksi dengan lingkungan mengenai dunia sekitar serta mengenal pergaulan hidup yang berlaku dilingkungannya. Menurut Baumrind ada tiga gaya pola asuh orang tua : otoritatif, otoriter, dan primisif yang digunakan untuk mengasuh anak berdasarkan tingkatnya pengasuhan (Nurtering), tuntutan (Maturity demands), komunikasi dan kontrol terhadap prilaku anak.

Sikap pola asuh menunjukkan perbedaan alamiah yang muncul dari nilai-nilai yang diajarkan, perlakuan orang taua, perilaku responsif dan tuntutan (Ribeiro, 2009 )mempunyai dampak terhadap perkembangan anak, dimana optimalisasi perkembangan anak dalam kehidupan bermasyarakat itu akan bergantung bagaimana dengan orang-orang di sekitar lingkungan mereka berada, lebih-lebih kedua orang tuanya. Hal itu akan menentukan kepribadian anak untuk kehidupannya di masa mendatang

Untuk mengatasi masalah tersebut salah satunya dengan meningkatkan motorik halus anak melalui faktor eksterna simulasi yaitu dengan memberikan berbagai permainan yang mampu memicu kreatifitas anak salah satunya adalah kolase, selaras dengan penelitian Lutfiasari, 2016, tehnik permainan kolase menjadi bagian pembelajaran, agar anak mendapatkan stimulus yang baik untuk melatih koordinasi geraknya.

Kemampuan balita melakukan sosialisasi dan kemandirian merupakan salah satu poin utama penilaian perkembangan. Kemampuan balita melakukan sosialisasi dipengaruhi oleh pola asuh. Pola asuh ada beberapa macam salah satunya ada non otoritatif. Hal ini sesuai dengan penelitian Komariah, Farid, \& Effendi (2017) yang menyatakan pola asuh non otoritatif berhubungan dengan kekurangan kemampuan sosialisasi anak. Perilaku ibu yang hangat berkaitan dengan kemampuan sosialisasi anak dalam membina hubungan interpersonal dengan teman sebaya dan lingkungan sosial. Pola asuh orang tua memilik pengaruh yang besar pada perilaku anak.

Peran aktif dari orang tua dan lingkungan merupakan usaha yang tepat dalam mengembangkan potensi anak secara optimal (Suherman, 2000). Berdasarkan hasil penelitian Budiman, ada pengaruh pola asuh otoritatif, permisif, dan otoriter terhadap perkembangan anak. Disarankan orang tua agar mengetahui dan menerapkan pola asuh yang baik bagi perkembangan anaknya.

Hasil pada kegiatan pengabdian masyarat, pentingnya diperlukan kegiatan stimulasi dan intervensi dini tumbuh kembang anak. Kegiatan stimulasi dan intervensi dini penyimpangan tumbuh kembang anak dapat dilakukan dalam bentuk kemitraan antar keluarga (orangtua, pengasuh anak dan anggota keluarga lainnya), masyarakat (kader kesehatan, tokoh masyarakat dan organisasi profesi) serta tenaga profesional lainnya (tenaga kesehatan, pendidikan dan sosial), sehingga tidak hanya meningkatkan status pertumbuhan anak tetapi juga tingkat perkembangan mental, sosial, emosional, bahasa dan lainnya. Hasil yang diharapkan agar terjadi peningkatan dan perbaikan kualitas perkembangan anak sebelum memasuki 
pendidikan formal.

\section{KESIMPULAN}

Sebagian besar anak di PGTK Pelita Hati Rancabango Tarogong Kaler Garut Kota hampir seluruh anak berada pada kategori normal (87.8\%). Masih terdapatnya anak dengan suspect yaitu sebagian kecil $(6,06 \%)$ Suspect juga menunjukkan bahwa anak gagal melakukan satu atau dua item pada persentil 75-95\%, dimana sebesar 75\%$95 \%$ anak pada usia tersebut seharusnya sudah mampu melakukan, sehingga penting bagi petugas kesehatan untuk memberikan pendidikan kesehatan kepada orangtua untuk meningkatkan kesadaran orangtua terkait pentingnya pemberian stimulasi deteksi intervensi dini pada anak untuk merangsang perkembangan anak sesuai usianya. Selain itu, petugas kesehatan perlu memberikan pemahaman kepada para pendamping anak disekolah maupun di tempat pendidikan anak usia dini agar dapat pula memberikan stimulasi melalui proses bermain yang menyenangkan bagi anak.

\section{UCAPAN TERIMA KASIH}

Ucapan terima kasih diberikan kepada pimpinan STIKes Karsa Husada Garut yang telah memberikan dana kegiatan pengabdian ini dan juga kepada pihak Sekolah PGTK PAUD PELITA HATI yang telah membantu pelaksanaan pengabdian masyarakat

\section{DAFTAR PUSTAKA}

Anna Tjandrajani, Attila Dewanti, Amril A. Burhany, Joanne Angelica Widjaja, Keluhan Utama pada Keterlambatan Perkembangan Umum di Klinik Khusus Tumbuh Kembang RSAB Harapan Kita, Sari Pediatri, Vol. 13, No. 6, April 2012
Atmarita. "Nutrition problem in

$$
\begin{aligned}
& \text { Indonesia." An Integrated } \\
& \text { International Seminar and Workshop } \\
& \text { on LifestyleRelated Diseases. } \\
& \text { Yogyakarta: Universitas Gajah Mada, } \\
& \text { 19-20 Maret } 2005
\end{aligned}
$$

Budiman. (2015) Pengaruh Pola Asuh Orang Tua terhadap Perkembangan Anak Usia Dini

Celikkiran, S., Bozkurt, H., Coskun, M. 2015. Denver Developmental Test Findings and their Relationship with Sociodemographic Variables in a Large Community Sample of 0-4Year-Old Children. Noro Psikiyatri Ars. 2015 Jun; 52(2):180-184. doi: 10.5152/npa.2015.7230

Depkes, RI. 2008. Pedoman pelaksanaan

stimulasi, deteksi dan Intervensi Dini Tumbuh kembang Anak di Tingkat pelayanan Kesehatan Dasar. Jakarta, Depkes RI Direktorat Jenderal PPM \& PLP.

Greenwood, B. (2013). The Baumrind theory of parenting styles. GlobalPost-International News. Retrieved December 15, 2013 from everyday.globalpost.com/baumrindtheory-parenting-styles-6147.html

Hartanto, F., Selina, H., H, Z., \& Fitra, S. (2011). Pengaruh Perkembangan Bahasa Terhadap Perkembangan Kognitif Anak Usia 1-3 Tahun. Sari Pediatri, 12(6), 386-390.

Kemenkes RI, 2016. Pedoman pelaksanaan Stimulasi, Deteksi dan Intervensi Dini Tumbuh Kembang Anak. Buku_SDIDTK_Bab_I-V.pdf.

Kemendiknas. 2010. Pembinaan Pendidikan. Jakarta: Kemendiknas Kurniawan, R., Muhimmah, I., Jannah, HR. 2016. Sistem Monitoring Perkembangan Anak Berbasis Denver Development Screening Test (DDST/Denver II).Jurnal Teknologi Industri, vol. 22, no. 44 DOI: https://doi.org/10.20885/.v22i4.743N 
ugroho, Heru Santoso wahito. (2009). Petunjuk praktis denver

Developmental screening Test. Jakarta: EGC

Komariah, N., Farid, \& Effendi, S. H. (2017). Faktor-Faktor yang Berhubungan dengan Kemampuan Sosialisasi Anak. Sari Pediatri, 18(5), 373-378

Lutfiasari Desy. 2016 Pengaruh Pemberian Permainan Tehnik Kolase Terhadap Perkembangan Motorik Halus Pada Anak Prasekolah Di TK Dewi Sartika.

Pusponegoro, H. 2006. Gambaran Kemampuan Motorik Kasar. Retrievedhttp://www.medicaljournal. co.cc/2013/-02/gambaran

Kemampuanmotorik-kasarpada.html

Revina. 2010. Perkembangan Psikologi Anak Usia Dini.

Ribeiro, L. L. (2009). Construction and validation of a four parenting styles scale. Thesis. Humboldt State University.

Santrock, J.W. 2010. Psikologi Pendidikan. Jakarta: Prenada Media

Seotjinigsinh dan Ranuh, U. N (2014). Tumbuh Kembang Anak Edisi 2. Jakarta : EGC. Buku Kedokteran

Solihin, (2013) Kaitan Antara Status Gizi, Perkembangan Kognitif, dan Perkembangan Motorik Pada Anak Usia Prasekolah.

Susilaningrum, Rekawati, dkk. 2013. Asuhan Keperawatan Bayi Dan Anak. Jakarta : Salemba Medika

Suherman. (2000). Buku saku perkembangan anak. Jakarta: EGC

Theeranate K, Chuengchitraks S . 2005. Parent's Evaluation of Developmental

Status (PEDS) detects developmental problems compared to Denver II. Journal of the Medical Association of Thailand = Chotmaihet Thangphaet (01 Nov 2005, 88 Suppl 3:S188
Triastutik, 2018. Hubungan bermain gadget dengan tingkat perkembangan anak.

http://repo.stikesicmejbg.ac.id-92)

Wong, DL (2009). Buku Ajar Keperawatan Pediatrik Volum 1. Alih bahasa Agus Sutarna dkk, Jakarta :EGC. 